\title{
Modelling of energy consumption at construction of high-rise buildings
}

\author{
Elena $\mathrm{Korol}^{l^{*}}$ and Oleg Korol ${ }^{l}$ \\ ${ }^{1}$ Moscow State University of Civil Engineering, Yaroslavskoe shosse, 26, Moscow, 129337, Russia
}

\begin{abstract}
High-rise building structures in the course of its erection suppose primary use of methods provided for erection, concrete and external finishing works. Erection works do not differ significantly from usual ones: traditional equipment, accessories and techniques are used which are based on erection of structures in project position using a crane. Structures to be assembled in building frame include steel columns and beams, wall panels, form elements of columns, walls and floor structures. We can note heightened attention to operational control for quality of erection, but it is attributable to all works in the course of high-rise construction. During high-rise erection by means of cast in-situ reinforced concrete all formworks to be used do not have any special differences except systems specially designed for high-rise erection using sliding formwork or vertical traveling forms. In these systems special attention is paid to safety of elevated works. Working methods of placement and curing of concrete and structures as a whole remain traditional - the requirements for controlling such operations become toughened. The most evident differences in high-rise erection with regard to equipment, machinery and accessories used are in means provided for load transportation and safety of works at heights. Particularity of internal finishing works which are also obligatory during construction of skyscrapers allows not considering them in as technological differences from usual construction as far as the «height» of its execution is limited by height of particular floor and determined by price and building class.
\end{abstract}

\section{Introduction}

High-rise erection process consists of execution of well-known technological processes on installation and erection of building structures: foundations, walls, columns etc. However particular features of such structures and factor of high altitude at which works should be performed predetermine several differences in methods of work execution expressed in appearance of new methods, mechanical aids, types of work and design documentation.

The construction site of High-rise erection is characterized by the integration of various types of energy consumers. The main ones are machinery and equipment, technological processes, as well as infrastructure of the construction site.

\footnotetext{
* Corresponding author: KafedraGKK@mgsu.ru
} 


\section{Mechanical aids and equipment to be used within high-rise erection}

\subsection{Cranes designated for high-rise erection}

According to current data the use of traditional column cranes within building construction is limited by load-lifting height at $70-80 \mathrm{~m}$ (in case of larger height the ratio of parameters «safety, lifting capacity, weight, cost» becomes nonoptimal). Lifting of loads at 130-140 m is provided by attachment crane; its vertical tower can be detached on erected structures of building under construction. Integrated use of column cranes (erection phase at height up to $50-60 \mathrm{~m}$ ) and attachment cranes (higher part of building) is used rather often when erecting buildings of height up to $130 \mathrm{~m}$. Optimal ratio of parameters «load capacity, weight, cost» of attachment cranes is limited in case of building height of $130 \mathrm{~m}$ and more; however some cranes of this type are able to provide lifting of load up to $150 \mathrm{~m}$ in height. This is the field of application of selfclimbing cranes that do not have limitations in load lifting height. These cranes are fixed on hard stocks of stiffening cores or on external outline of building and its height of tower and attachment and movement structure provide crane operation in levels $30-40 \mathrm{~m}$. After erection of building all cranes will be demounted and get down in parts using winches. According to practices of construction a technique is used when cranes of such type are preserved and remain on the roof for subsequent use during major repairs.

\subsection{Equipment designated for transportation of concrete mixture to floors}

Buckets and stationary concrete pumps are primarily used for transportation of concrete mixture to height. The use of buckets is defined by small volumes of monolithic works in precast frames. The use of concrete pumps is more specific for solid-cast frames. In this case the majority of concrete pumps of this type provide effective pumping of mixture at $40-50 \mathrm{~m}$ in vertical line, thus mixture supply at larger height is provided in stages using several pumps and intermediate containers. Placement of concrete mixture directly into cast formwork is performed using concrete placement booms installed on self-lifting or vertical traveling pillar supports of height 30-40 m. Cycles of vertical displacement of such devices correspond to erection rate of 3-4 floors. Primarily the supply of concrete mixture to working levels of high-rise buildings currently do not cause a problem and technically it is well cared.

\subsection{Equipment designated for lifting of loads, personnel and for works on face of building}

When erecting high-rise buildings the traditional problem of lifting small loads at the stage of finishing works is added by question of obligatory lifting of construction personnel at the stage of building frame erection. Special cargo-and-personnel lifting machines with lifting capacity up to 3 tones and personnel capacity up to 15-20 men with average lifting height up to $300 \mathrm{~m}$ are used for these purposes. Installation of a lifting machine is performed after erection of 5-10 floors of superstructure; the machines are provided for both finishing works and lifting of personnel to floors located near working levels of erection or concrete works. Number and type of lifting machines is defined on the base of building configuration and requirements for arrangement of construction works on site.

\section{Technological features of foundation work}


High-rise buildings are widely erected with developed embedded substructure designated for bearing vertical and tipping loads of building tower. The substructure area as a rule is larger than superstructure area of a building in 1.5-2 times and depth of foundation is 10$20 \mathrm{~m}$.

\subsection{Stage of excavation works}

Heavy increase of depth of foundation in comparison with traditional depth of 3-4 m has led to inability to perform common excavation of high-rise building foundation using natural slopes of excavations that enlarge area of building foundation in 2-3 times. Substructure development methods «diaphragm wall» and methods of land cofferdam and fender have been actively used in order to solve these problems. It should be noted that these methods require special equipment and accessories.

Technological problems of deep foundation installation with vertical fencing of slopes are based on provision of stable release of walls enclosing ditch for foundation and ground as a whole up to the moment of creation of spacely rigid structure of building substructure. In order to solve this problem vertical fencing of slopes are mostly combined with external walls of building substructure using various methods for stiffening fences and hidden excavation works by means of small construction equipment together with installation of bearing piles in the course of excavation. These questions come up sharply when erecting highrise structures in fully developed areas.

Excavation works in the course of substructure installation are usually performed using a crane-type excavator equipped with front or bottom-dump bucket. In this case excavation is performed by levels in 3-4 m. Loaders and mini-excavators can be used in case of using methods of hidden excavation; earth excavation from trench can be performed by cranes. Excavation works as a rule are performed by specialized construction organizations equipped with respective excavation and transportation means.

Stage of excavation works in high=rise construction is additionally accompanied by special activities related to water drawdown and protection from ground water. Technology of execution of such works requires use of special equipment.

\subsection{Stage of foundation slab installation in high-rise buildings}

Foundation slab installation in the course of works on development of high-rise building substructure represents complicated and rather long individual stage. Rather often structure of foundation of high-rise buildings is designed in the form of pile-and-slab foundations that introduces installation of foundation slabs by works on installation of cast in-situ piles.

Foundation slabs of high-rise buildings are widely made of cast in-situ reinforced concrete and have rather complex basic geometry in plan with thickness $2-4 \mathrm{~m}$ and total volume of $3000-4000 \mathrm{~m} 3$. Practice of domestic construction allows specifying the following main technological problems related to its installation:

1. Reinforcement cage of foundation slabs represents heavy lower and upper multilayer nets resting on vertical reinforcement bars with system step $0.5-1 \mathrm{~m}$ and with local additional reinforcement in area of bearing columns and pillars. Due to that the reinforcement cage becomes an independent structure that requires solution on provision of stability and safety at all stages of its installation.

2. Provided high-strength concrete (usually class B40 and higher with low-cement content and high consistency of concrete mix) significantly increases requirements for processes of production, transportation and placement of mixture.

3. Requirements for continuity of foundation slab concreting in combination with its large thickness and area of concreting zones lead to: 
- Necessity of mixture retardation after placement to 12-20 hours;

- Use of concrete placers of higher performance in combination with use of greater quantity of transportation means;

- Use of greater number of vibrators and thorough provision of mixture vibration for all local volumes of placement.

4. Holding of massive foundation slabs after placement of mixture is performed in compliance with extremely strict temperature requirements for rates of concrete heatingcooling and temperature differences between central and edge zones.

\subsection{Stage of installation of vertical and horizontal structures of substructure}

Structures of walls and floors of building substructure made of cast in-situ reinforced concrete do not have any significant differences within execution of formworks, reinforcement or finishing works. They are primarily characterized by high solidity (columns, pylons, bearing walls and beams), intensive reinforcement and use of highstrength concrete. Intensity of concreting is greatly reduced in comparison with foundation slabs within its installation; method of concrete works is within the traditional frameworks of using automobile or stationary concrete pumps with placer masts or it is performed using method «crane-bucket». Respectively there is no problem when using cranes of any types for provision of formworks or concrete works.

\subsection{Stage of erection of superstructure, enclosing structures, finishing works}

Erection of superstructure is performed using well-known technologies and technical means. Vertical enclosing structures (external walls of building) shall be installed either within the stage of floor erection (erection of wall panels), or as an individual set of works following works of installation of building bearing structures. In the latter case such works will be performed in levels with delay from works on structure erection in 5 or more floors.

Finishing works to be performed during high-rise construction shall be executed in levels in the course of its construction. Such level structure of finishing works is directly related to presence of crawl floors in a building so far as these floors are designated for solving matters of installation of roofing system and provision of temporary supply of finishing work areas with water, heat and energy.

\section{Results}

The construction site is characterized by the integration of various types of energy consumers. The main ones are machinery and equipment, technological processes, as well as infrastructure of the construction site. Therefore, integrated schedule for the consumption of fuel and energy resources can be presented in the form of a diagram of the daily fuel consumption by all types of energy consumers in unified units of measurement (kg of fuel equivalent), the general view is shown in Figure 1. 


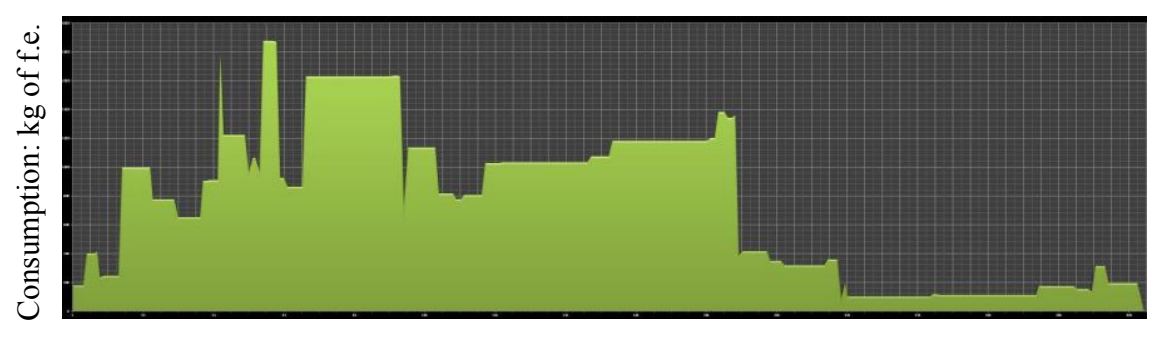

Days

Fig. 1. The general view of the daily fuel consumption schedule

The calculation of fuel and energy resources consumption by different consumers occurs with the calendar factor to their hourly expenditure and the degree of employment during working hours. In general, the formula (1) for calculating the consumption of fuel and energy resources by various consumers is:

$$
W \text { consumer }=Q \text { hour } * k * T \text { day } * T \text { work } * B,
$$

where $W$ consumer - the consumption of the fuel and energy resources consumer, $Q$ hour - the hourly consumption of fuel and energy resources by the consumer, $k$ - the calendar factor for the hourly expenditure of fuel and energy resources, $T$ day - the duration of the working day,

$T$ work - the duration of the works,

$B$ - the level of employment of fuel and energy resources consumers.

Modeling of energy and fuel resources consumption for high-rise erection monolithic housing facilities, as an example, revealed that the variation in the timing of the construction (for the same duration of works) significantly affects the integral consumption of energy resources during the production of the construction site. Thus, calculations will decrease the overall consumption of energy resources by $27 \%$ at the start of work in April compared with the beginning of October (Figure 2).

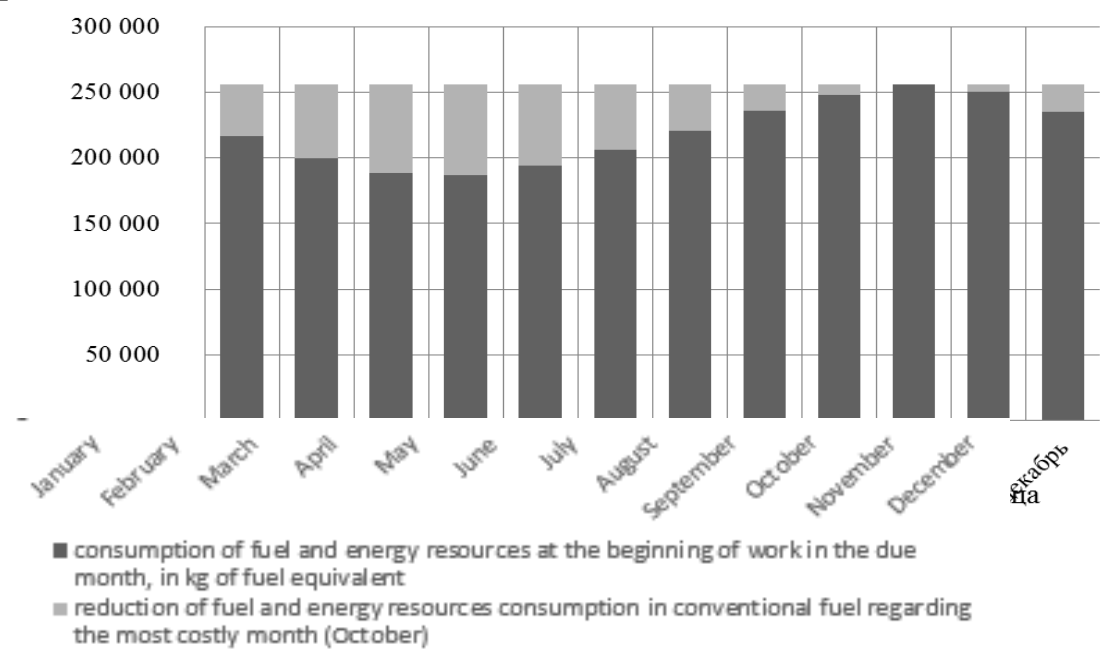

Fig. 2. Diagram of fuel and energy resources consumption changes depending on selection the month of beginning of the construction works 


\section{Discussion}

The carried-out analysis of a consumption of energy resources in a generalized view on the integrated groups of consumers - machines, mechanisms and the equipment; technological processes and infrastructure of the building site I have revealed the following features.

Variation of terms of the beginning of construction at preservation of identical duration of works has revealed essential differences in a consumption of energy resources for separate groups of consumers. Consumption of energy resources by the "Machines, Mechanisms and Equipment" group at the beginning of construction in October is $13,7 \%$ higher, than at postponement of the beginning of construction for April.

The made comparative analysis of consumption of energy resources is submitted by all types of cars, mechanisms and equipment in table 1 . The biggest energy consumers in this group are the tower crane $(21 \%)$ and the stationary concrete pump (19\%), the smallest painting $(0,03 \%)$ and plaster stations $(0,11 \%)$ at the most adverse beginning of works in October.

Table 1. Consumption of Fuel and energy resources (FER) by cars, mechanisms and the equipment at various terms of the beginning of construction

\begin{tabular}{|l|c|c|}
\hline \multirow{2}{*}{ Machines, mechanisms and equipment } & \multicolumn{2}{|c|}{ FER expense in \% } \\
\cline { 2 - 3 } & october & april \\
\hline Bulldozer & 0,43 & 0,44 \\
\hline Mobile crane & 6,7 & 6,5 \\
\hline Tower crane & 21 & 23 \\
\hline Mini-loader & 3,2 & 3,5 \\
\hline Excavator & 8,3 & 8,1 \\
\hline Vibropogruzhatel & 1,4 & 1,4 \\
\hline Vibrotamper & 0,26 & 0,23 \\
\hline Welding transformer & 6,76 & 6,5 \\
\hline Concrete pump & 3,2 & 3,07 \\
\hline Avtobetonosmesiteli & 4,5 & 4,3 \\
\hline Stationary concrete pump & 19,4 & 17,1 \\
\hline Construction elevator & 0,98 & 1,08 \\
\hline Plaster station & 0,11 & 0,15 \\
\hline Compressor & 8,78 & 8,85 \\
\hline Painting station & 0,03 & 0,04 \\
\hline Electric tool & 7,5 & 8,5 \\
\hline Electric winch & 6,4 & 6,12 \\
\hline Table for reinforcing works & 0,73 & 0,73 \\
\hline & 100 & 100 \\
\hline
\end{tabular}

Consumption of energy resources by the Technological Processes group at the beginning of construction in October in 8 above, than at postponement of the beginning of construction for April. It is explained, first of all, by the fact that the summer period of construction heat treatment of newly-laid concrete mix is carried out only for the purpose of an intensification of set of durability of concrete and reduction of terms of construction of the facility. By production of monolithic works during the winter period it is necessary to provide a set of critical durability of concrete in the conditions of the negative temperature of external air that is connected with increase in duration and power of warming up of reinforced concrete designs of walls, columns, heating of overlappings and also concrete preparation and a base plate.

The made comparative analysis of consumption of energy resources by the Technological Processes group is presented in table 2. At the most adverse term the 
beginning of works in October the biggest energy consumers to this group are processes of electrowarming up of walls and columns $(50 \%)$ and an electrical heating of overlappings $(31 \%)$, the smallest - heating of concrete preparation and a base plate $(1 \%)$ and was warmed soil vertical electrodes $(6 \%)$.

Table 2. Consumption of FER by the Technological Processes group at various terms of the beginning of construction

\begin{tabular}{|c|c|c|}
\hline \multirow[t]{2}{*}{ Technological processes } & \multicolumn{2}{|c|}{ FER expense in $\%$} \\
\hline & october & october \\
\hline Electrowarming up of walls and columns & 49,6 & 33,8 \\
\hline Electrical heating of overlappings & 31,2 & 2,5 \\
\hline Heating of concrete preparation and base plate & 0,9 & 0 \\
\hline Having warmed soil vertical electrodes & 5,6 & 20,4 \\
\hline Heating of fittings electroheaters & 12,6 & 43,3 \\
\hline Total & 100 & 100 \\
\hline
\end{tabular}

Consumption of energy resources by the Infrastructure of the Building Site group at the beginning of construction in October is $60 \%$ higher, than at postponement of the beginning of construction for April, t. to costs of heating of points of heating of working and household rooms, and in lighting - due to reduction of duration of light day increase.

The made comparative analysis of consumption of energy resources by the Infrastructure of the Building Site group is presented in table 2 At the most adverse term the beginning of works in October by the biggest consumers of energy resources in this group infrastructure elements of the building site - heating of household rooms $(34 \%)$ and points of heating of workers $(25 \%)$ are. Calculation and comparison of a consumption of energy resources on publicizing of external works at the beginning of a stroitelsv in October increases by $85 \%$, and the electricity consumption on emergency and security lighting changes slightly. The comparative consumption of energy resources on basic elements of infrastructure is presented to the building site in table 3 .

Table 3. Consumption of FER by the Infrastructure of the Building Site group at various terms of the beginning of construction

\begin{tabular}{|c|c|c|}
\hline \multirow[t]{2}{*}{ Infrastructure of the building site } & \multicolumn{2}{|c|}{ FER expense in $\%$} \\
\hline & october & october \\
\hline Point of heating of workers & 25,2 & 2,02 \\
\hline Heating of household rooms and points of protection & 34,1 & 41,3 \\
\hline Lighting of household rooms and points of protection & 2,9 & 4,8 \\
\hline Security lighting & 15,09 & 23,6 \\
\hline Emergency lighting & 10,9 & 17,9 \\
\hline $\begin{array}{l}\text { Publicizing of external works searchlights of } 2 \mathrm{~kW} \\
\text { (working day } 24 \text { hours) }\end{array}$ & 11,7 & 10,3 \\
\hline $\begin{array}{ll} & \text { Total } \\
\end{array}$ & 100 & 100 \\
\hline
\end{tabular}




\section{Conclusion}

The development of a methodological base for organizational and technological modeling in the part of building diagrams for the consumption of energy resources during the erection of high-rise building structures was proposed. The construction of energy consumption diagrams in the period of the complete building construction cycle allows planning and flexibly adjusting the consumption of energy resources both for individual types of consumers and in general.

Varying the timing of the beginning and completion of construction in the construction of a diagram of energy consumption allows you to achieve a reduction in energy consumption during the erection of high-rise building structures to $20-40 \%$.

\section{References}

1. G.I. Abdullayev, V.Z. Velichkin, T.N. Soldatenko, Magazine of Civil Engineering, 3, 43-50 (2013)

2. P.G. Grabovyi, E.A. Gusakov, A.M. Krygina, Real Estate: Economics, Management. 2. Pp. 14-19 (2013)

3. P.G. Grabovyi, L.A. Manukhina, Real Estate: Economics, Management. No 1-2. Pp. 6-8. (2014)

4. G. Keshavarz, M., E.K. Zavadskas, Z. Turskis, J. Antucheviciene, Computers and Industrial Engineering. 112, pp. 156-174 (2017)

5. K. Kianpour, A. Jusoh, A. Mardani, K.M. Nor, E.K. Zavadskas, Sustainability (Switzerland). 9, iss.9. (2017)

6. E.A. Korol, Real estate: economics, management. 2. Pp.32-35 (2013)

7. E.A. Korol, P.B. Kagan, Collection of materials of the VI International Scientific and Practical Confuel and energy resources Pp. 100-107 (2014)

8. E.A. Korol, N.S. Shushunova, Increase the level of environmental safety of a metropolis in the construction of "green" buildings Scientific Review. No 7. Pp.144147 (2014)

9. E.A. Korol, N.S. Shushunova, Technologies of eco-building of exploited roofing coatings Scientific Review. No. 8. Pp.42-45 (2015)

10. E.A. Korol, N.S. Shushunova, Modern technologies of reconstruction of roofing coatings in eco-building, Construction and reconstruction No 3 (65). Pp. 114-118. (rus) (2016)

11. P.P. Oleinik, A.L. Bolsherotov, Industrial and civil construction. No. 10. Pp. 20-21. (rus) (1987)

12. P.P. Oleinik, V.I. Brodsky, Industrial and civil construction. No 12. Pp. 30-32. (2012)

13. P.P. Oleinik, V.I. Brodsky, Basic requirements for the composition and content of the project for the production of works Technology and organization of construction. No. 3 (4). Pp. 35-38 (2013)

14. T. Saati T. Decision-making. The method of analyzing hierarchies. Moscow.: Radio and Communication, P. 278. (1993)

15. Zh.G. Mogilyuk, S.I. Zavalishin, M.S. Khlystunov, Scientific review, No. 7-1, 241244 (2014)

16. Zh.G. Mogilyuk, M.S. Khlystunov, V.I. Prokopiev, International Journal for Computational Civil and Structural Engineering, 10, 2, 120-129 (2014) 
17. S.I. Zavalishin, Zh.G. Mogilyuk, M.S. Khlystunov, Scientific review, 7, 245-248 (2014)

18. S.I. Zavalishin, M.S. Khlystunov, Zh.G. Mogilyuk, Ecology of urbanized territories, 4, 35-41 (2015)

19. V.V. Poduvaltsev, M.S. Khlystunov, Zh.G. Mogilyuk, Safety in the technosphere, 3, 2, 14-17 (2014)

20. V.I. Prokopiev, M.S. Khlystunov, Zh.G. Mogilyuk, International Journal for Computational Civil and Structural Engineering, 2, 105-110 (2014)

21. M.S. Khlystunov, V.I. Prokopiev, Zh.G. Mogilyuk, Procedia Engineering, 111, 672 (2015)

22. M.S. Khlystunov, Zh.G. Mogilyuk, Safety of buildings, 3, 16 (2003) 